\title{
Antioxidant and Hypoglycemic Effects of Momordica cochinchinensis Spreng. (Gac) Aril Extract on Reproductive Damages in Streptozotocin (STZ)-Induced Hyperglycemia Mice
}

\author{
Efectos Antioxidantes e Hipoglucémicos del Extracto de Aril de Momordica cochinchinensis \\ Spreng. (Gac) sobre los Daños Reproductivos en Ratones con Hiperglucemia Inducida por \\ Streptozotocin (STZ)
}

\begin{abstract}
Apichakan Sampannang'; Supatcharee Arun'; Wannisa Sukhorum'; Jaturon Burawat ${ }^{1}$; Somsak Nualkaew ${ }^{2}$; Chanwit Maneenin ${ }^{3}$; Bungorn Sripanidkulchai ${ }^{4}$ \& Sitthichai Iamsaard ${ }^{1,4}$
\end{abstract}

SAMPANNANG, A.; SUPATCHAREE A.; SUKHORUM, W.; BURAWAT, J.; NUALKAEW, S.; MANEENIN, C.; SRIPANIDKULCHAI, B. \& IAMSAARD, S. Antioxidant and hypoglycemic effects of Momordica cochinchinensis spreng (gac) aril extract on reproductive damages in streptozotocin (STZ)-induced hyperglycemia mice. Int. J. Morphol., 35(2):667-675, 2017.

SUMMARY: The aim of present study was to investigate the effect of Momordica cochinchinensis (Gag) aril (GA) aqueous extract on male reproductive system of streptozotocin (STZ)-induced hyperglycemia (HG) mice. GA were extracted with distilled water (DW) and analyzed for in vitro antioxidant capacities. ICR male mice were divided into 7 groups: 1) control, 2) DW, 3) GA 1000 mg/kg $\mathrm{BW}$, 4) HG, 5) HG + glibenclamide, 6 and 7) HG + GA 500 and $1000 \mathrm{mg} / \mathrm{kg} \mathrm{BW}$ respectively (7 mice/ group). In HG groups, mice were induced by STZ at single dose $(150 \mathrm{mg} / \mathrm{kg} \mathrm{BW})$. They were treated for consecutive 35 days. All groups were compared for blood glucose levels, weights and histopathologies of reproductive organs, sperm concentration including testicular tyrosine phosphorylation protein patterns by Immuno-Western blotting. The results showed that GA processed antioxidant activities and could significantly decrease blood glucose levels and increase sperm concentration in HG mice. Moreover, GA could change the density of a testicular $70 \mathrm{kDa}$ protein in HG-GA groups. In conclusion, GA extract could improve hyperglycemia and male reproductive damages in STZ-induced HG mice.

KEY WORDS: Momordica cochinchinensis aril; Streptozotocin (STZ); Testicular damage; Testicular tyrosine phosphorylated protein; Hyperglycemia (HG) mice.

\section{INTRODUCTION}

Diabetes mellitus (DM), also called hyperglycemia, is a group of chronic disorders in glucose metabolism caused by insulin impaired secretion from pancreatic beta cells resulting in elevating glucose levels. DM is involved in many diseases such as cardiovascular disease (de Ferrant et al., 2014), diabetic peripheral neuropathy, diabetic retinopathy (Wang et al., 2014) and diabetic nephropathy (Jin et al., 2014). Moreover, it has been reported that DM affects the male reproductive system of both diabetic patients and animals induced by chemicals (Baccetti et al., 2002; Ballester et al., 2004). In addition, the reductions of sperm motility, viability, concentration, normal morphology and sex hormones have been observed in DM condition. It seemed that testicular tyrosine phosphorylation patterns, in streptozotocin (STZ)-induced hyperglycemia (HG) rats were different from control (Ballester et al.). Interestingly, previous studies suggested that an increase in phosphorylation levels of testicular proteins caused by administration of antioxidant plant extracts could be ascribed to testosterone production and spermatogenesis (Iamsaard et al., 2013; 2014). In recent studies, it has been shown that medicinal plants possessing

\footnotetext{
${ }^{1}$ Department of Anatomy, Faculty of Medicine, Khon Kaen University, 123 Mittaparb Road, Maung, District, Khon Kaen, 40002, Thailand.

${ }^{2}$ Department of Pharmaceutical Sciences, Faculty of Pharmacy, Mahasarakham University, Mahasarakham, 44150, Thailand.

${ }^{3}$ Department of Anatomy, College of Medicine and Public Health Ubonratchathani University, 34190, Thailand.

${ }^{4}$ Center for Research and Development of Herbal Health Product, Faculty of Pharmaceutical Sciences, Mittaparb Road, Khon Kaen, 40002, Thailand.

Grants: This project was financially supported by the invitation research grants, Faculty of Medicine, Khon Kaen University (No.IN-58123).
} 
SAMPANNANG, A.; SUPATCHAREE A.; SUKHORUM, W.; BURAWAT, J.; NUALKAEW, S.; MANEENIN, C.; SRIPANIDKULCHAI, B. \& IAMSAARD, S. Antioxidant and hypoglycemic effects of Momordica cochinchinensis spreng (gac) aril extract on reproductive damages in streptozotocin (STZ)-induced hyperglycemia mice. Int. J. Morphol., 35(2):667-675, 2017.

antioxidants including Momordica cochinchinensis Spreng can significantly reduce blood glucose levels in diabetic patients and STZ-induced animals (Vajpeyi et al., 2007; Zhang et al., 2014).

M. cochinchinensis Spreng (gac) is a tropical plant found in many countries including Thailand. This plant was identified to have various phytochemical components (Ishida et al., 2004; Kubola \& Siriamornpun, 2011). These fruits have been reported to have antioxidant activity (Kubola \& Siriamornpun), anti-inflammatory effect (Jung et al., 2013), immunomodulatory activity (Tsoi et al., 2006), antitumor properties (Chuethong et al., 2007), anti-cancer activity (Zheng et al., 2014; Petchsak \& Sripanidkulchai, 2015). However, there was no report of the hypoglycemic effect of Gac aril (GA) on adverse male reproductive system in type- I DM animal model.

\section{MATERIAL AND METHOD}

Plant collection and extraction: $M$. cochinchinensis arils (GA) was cultured from January to May, 2014 at Kuchinarai district, Kalasin province, Thailand. The plants were authenticated for its actual species by Prof. Dr. Pranom Chantaranothai, Department of Biology, Faculty of Science, Khon Kaen University, Thailand and kept samples in the Herbarium (\#Apichakan Sampannang 01 [KKU]), Khon Kaen University, Thailand. First, the $8000 \mathrm{~g}$ of fresh red GA were mixed with distilled water at the ratio of 1 to 1 and blended. Then GA juices were filtered by the nylon cloth. The GA filtrate was dried using Spray dryer. Then the percentage (\% yield) of GA extraction was calculated by using below formula:

$$
\begin{aligned}
\% \text { yield of GA extraction }= & 839.88 \mathrm{~g} \text { of GA dried weight } \mathrm{x} 100 \\
& 8.000 \mathrm{~g} \text { of GA fresh weight } \\
= & 10.50
\end{aligned}
$$

\section{Antioxidant assays}

Determination of total phenolic compound (TPC): The TPC was measured by Folin-Ciocalteu's calorimetric method as modified by Singletonet al. (1999). The standard calibration was prepared by using the gallic acid (SigmaAldrich Co. Ltd., USA). Briefly, 1,580 $\mu$ l of distilled water and $100 \mu \mathrm{l}$ of Folin-Ciocalteau's reagents (Darmstadt, Germany) were added andmixed. After 8 minutes, $300 \mu$ of sodium carbonate $\left(\mathrm{Na}_{2} \mathrm{CO}_{3}\right)$ (E. Merck KG, Darmstadt, Germany) solution was added, mixed and then incubated for 2 hours. The absorbance of blue color was measured using UV-VIS spectrophotometer (Jasco V530, Japan) at 765 $\mathrm{nm}$.

Determination of total flavonoid content (TFC): The TFC was measured using calorimetric method as described by Bakaret al. (2009). The standard calibration was prepared by using the quercetin (Sigma-Aldrich Co. Ltd., USA). Twenty $\mu$ l of diluted GA extract and quercetin solution were added into test tubes. Briefly, $0.5 \mathrm{ml}$ of GA extract was mixed with distilled water $2.25 \mathrm{ml}$ and added $5 \% \mathrm{NaNO}_{2}$ solution $0.15 \mathrm{ml}$. After 6 minutes, $0.3 \mathrm{ml}$ of $10 \% \mathrm{AlCl}_{3} \cdot \mathrm{H}_{2} \mathrm{O}$ solution was added before $1 \mathrm{M} \mathrm{NaOH} 0.1 \mathrm{ml}$. The absorbance of pale yellow color was measured using UV-VIS spectrophotometer at $420 \mathrm{~nm}$. The concentration of total flavonoid content in GA extract was measured as milligram quercetin equivalent $(\mathrm{QE})$ per gram extract.

Determination of DPPH free radical scavenging activity: The scavenging effect was measured using 1,1-diphenyl-2picryl-hydrazyl (DPPH) assay based on method of BrandWilliamset al. (1995). The GA extract solutions in methanol with a series of concentrations were prepared. A standard calibration was prepared using the ascorbic acid (E. Merck KG, Darmstadt, Germany). Then $500 \mu \mathrm{l}$ of ascorbic acid or GA extract solutions were mixed with $500 \mu \mathrm{l}$ of $1 \mathrm{mM} \mathrm{DPPH}$ (Fluka, Switzerland) solution and incubated for 30 minutes. The absorbance of the resulting solution was measured by using UV-VIS spectrophotometer at $517 \mathrm{~nm}$. The radical scavenging capacity was calculated by using the following equation:

$\%$ DPPH radical scavenging $=\left(\mathrm{Abs}_{\text {control }}-\mathrm{Abs}^{\text {sample }}\right) / \mathrm{Abs}^{\mathrm{control}} \times 100$

$\mathrm{Abs}^{\mathrm{control}}$ is the absorbance of the control and $\mathrm{Abs}_{\text {sample }}$ is the absorbance in the presence of the sample. The different concentrations of standard and GA extract solutions were used to obtain percent radical scavenging curves for calculating the IC50 values that required to scavenging the $50 \%$ DPPH free radicals.

Determination of ferric reducing antioxidant power (FRAP): The total antioxidant activity was measured using ferric tripyridyltriazine (FeIII-TPTZ) complex as reported by Benzie \& Strain (1996). A standard calibration was prepared by using various concentrations of ascorbic acid (E. Merck KG, Darmstadt, Germany). Then 1,500 $\mu$ l of freshly prepared FRAP reagent (E. Merck KG, Darmstadt, Germany) was mixed with $50 \mu \mathrm{l}$ of ascorbic acid and GA extract solutions and warm at $37^{\circ} \mathrm{C}$ for 10 minutes. The absorbance was measured by using UV-VIS spectrophotometer at $593 \mathrm{~nm}$. The FRAP value of GA extract was calculated from an equation from linear standard curve. 
Table I. Treatment on each group of mice.

\begin{tabular}{lll} 
& & Treatment \\
Groups & Day 1 (via i.p.) & Days 4-39 (via gastric) \\
\hline Control & non & non \\
VehicleI+DW & 0.1 M Citrate buffer & DW \\
Vehicle II+GA1000 & 0.1 M Citrate buffer & GA extract $(1000 \mathrm{mg} / \mathrm{kg} \mathrm{BW})$ \\
HG+DW (Negative control) & STZ $(150 \mathrm{mg} / \mathrm{kg} \mathrm{BW)}$ & DW \\
HG+Gli (Positive control) & STZ $(150 \mathrm{mg} / \mathrm{kg} \mathrm{BW})$ & Glibenclamide $(\mathrm{Gli})$ \\
HG+GA500 & STZ $(150 \mathrm{mg} / \mathrm{kg} \mathrm{BW})$ & GA extract $(500 \mathrm{mg} / \mathrm{kg} \mathrm{BW})$ \\
HG+GA1000 & STZ $(150 \mathrm{mg} / \mathrm{kg} \mathrm{BW})$ & GA extract $(1000 \mathrm{mg} / \mathrm{kg} \mathrm{BW})$ \\
\hline
\end{tabular}

$\mathrm{BW}=$ body weight; $\mathrm{DW}=$ distilled water; $\mathrm{GA}=$ gac aril; $\mathrm{HG}=$ hyperglycemia; i.p.= intraperitoneal injection; $\mathrm{M}=$ molar; $\mathrm{STZ}=$ streptozotocin dissolved in $0.1 \mathrm{M}$ citrate buffer. $\mathrm{HG}$ groups (negative control, positive control, HG+GA500 and HG+GA1000); designed based on Muralidhara (2007). Day 1 = STZ injection. Days 4-39 = the treatment days.

Animals and treatment regime: Forty-nine ICR male mice, aged 6-8 weeks were purchased from National Laboratory Animal Center (NLAC), Mahidol University, Salaya, Nakhon Pathom, Thailand. Mice were acclimatized at Northeast Laboratory Animal Center (NELAC), Khon Kaen University, Thailand. This study was approved by the Animal Ethics Committee of NELAC, Khon Kaen University, Thailand, based on the Ethics of Animal Experimentation of the National Research Council of Thailand (ref. No. 0514.1.12.2/35 with record No. AEKKU-NELAC 29/2557). All mice were grouped and treated for consecutive 35 days (shown in Table I). All animals were measured the glucose levels from tail prick blood using blood glucose oxidase reaction monitoring system (Johnson \& Johnson Ltd.). Hyperglycemic (HG) mice were considered when the levels blood glucose was greater than $250 \mathrm{mg} / \mathrm{dl}$.
Epididymal sperm concentration: Sperm concentration was performed as described by Iamsaard et al. (2014). Sperm fluid was collected from epididymis and vas deferens. Its fluid was dipped and re-suspended in $1 \mathrm{ml}$ of PBS. Then sperm suspension was centrifuged (3000 r/min, $2 \mathrm{~min}$ ) to wash and separate the mature sperm pellet from its fluid. To analyze the sperm concentration, the sperm pellets were resuspended with $1 \mathrm{ml}$ PBS before dilution. The sperm dilutions (1:20 dilution) were counted for three times of each animal by using a Neubauer's counting chamber.

Histopathological examinations of the testes and epididymes: Right testis and cauda epididymis were fixed with $10 \%$ formalin and embedded with paraffin and sectioned by microtome about $5 \mu \mathrm{m}$ thicknesses. The testicular sections were deparaffinized and stained by

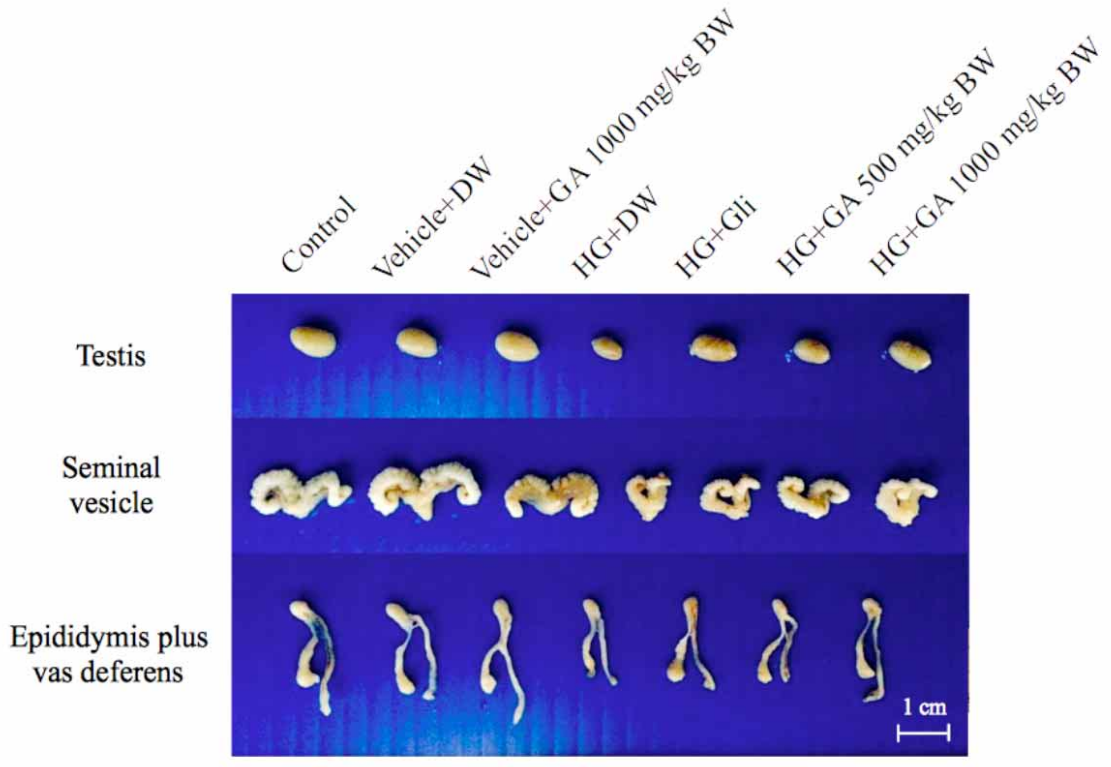

Fig. 1. Showing the representative morphology of male reproductive organs in the groups of control, vehicle + DW, vehicle + GA (1000 mg/kg BW), HG + DW, HG + Gli and HG + GA (500 and $1000 \mathrm{mg} / \mathrm{kg} \mathrm{BW)} \mathrm{respectively.} \mathrm{DW:} \mathrm{distilled} \mathrm{water,} \mathrm{Gli:} \mathrm{glibenclamide,}$ HG: STZ-induced hyperglycemia. 
hematoxylin and eosin before observing testicular histology under light microscope.

Investigation of testicular phosphotyrosine pattern: The total protein lysate of left side testis was prepared by homogenization with $1 \mathrm{X}$ Radioimmunoprecipitation assay buffer addedcocktail protease inhibitors (Cell Signaling Technology Inc., USA). The homogenate was centrifuged and the supernatant was collected to measure the total protein concentration by NANOdrop (NanoDrop ND-1000 Spectrophotometer V3.5 User's Manual, NanoDrop Technologies Inc., USA). Onehundred micrograms of total testicular proteins were separated by $10 \%$ sodium dodecyl sulfate polyacrylamide gel electrophoresis (SDSPAGE) and blotted onto nitrocellulose membrane to detect the intensity of phosphorylated protein by using the antiphosphotyrosine primary antibody (Santa Cruz Biotechnology INC., USA) overnight respectively, followed by incubation of antimouse secondary antibody (Santa Cruz Biotechnology INC., USA) respectively. Bovine serum albumin (AMRESCO®, USA) and epidermal growth factor (EGF)-like growth factor (Millipore Co., USA) were used as negative and positive controls.

Statistical analysis: All quantitative results were expressed as mean \pm standard deviation (SD). One-way analysis of variance (ANOVA) and Duncan test were used SPSS program (version 16) software to examine the significance of differences among sets of data. The level of statistical significance was $\mathrm{P}<0.05$.

Fig. 2. A. Showing effect of GA extract on absolute (1) and relative (2) weights of male reproductive organs. Each data point represented as mean \pm SD $(\mathrm{n}=7) . * \mathrm{P}<0.05$ was statistically significant. B. The blood glucose levels of all groups at day 4 and effect of GA on BGL at day 35 in STZ-induced hyperglycemic (HG) mice. DW: distilled water, Gli: glibenclamide. Each data point represented as mean $\pm \mathrm{SD}(\mathrm{n}=7) . * \mathrm{P}<0.05$ was statistically significant. C. Effect of gac aril (GA) extract on sperm concentration in all experimental groups induced hyperglycemia. Each data point represented as mean \pm SD $(n=7)$. * $\mathrm{P}<0.05$ was statistically significant. D. The testosterone levels of all experimental groups.
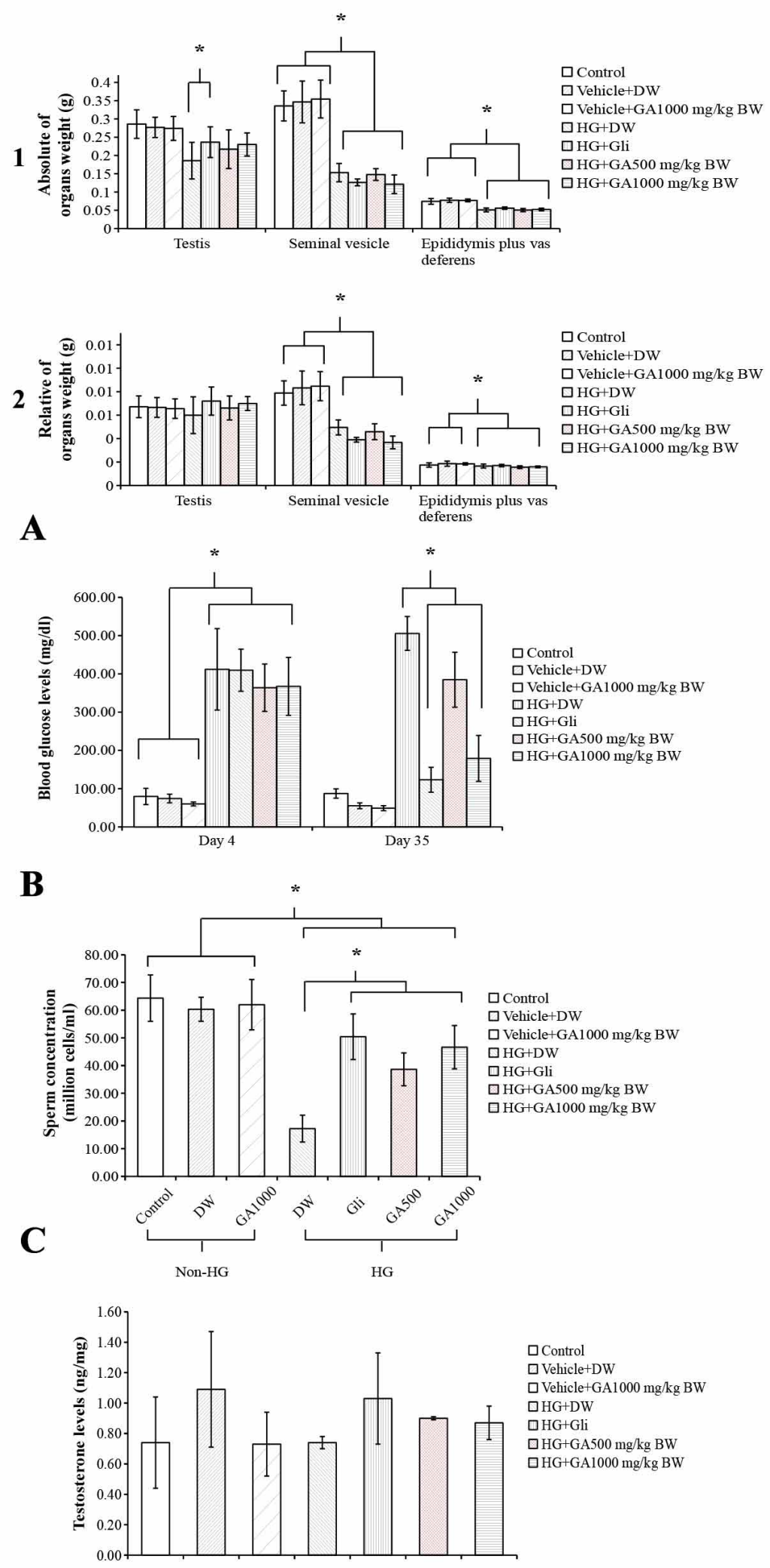

D 

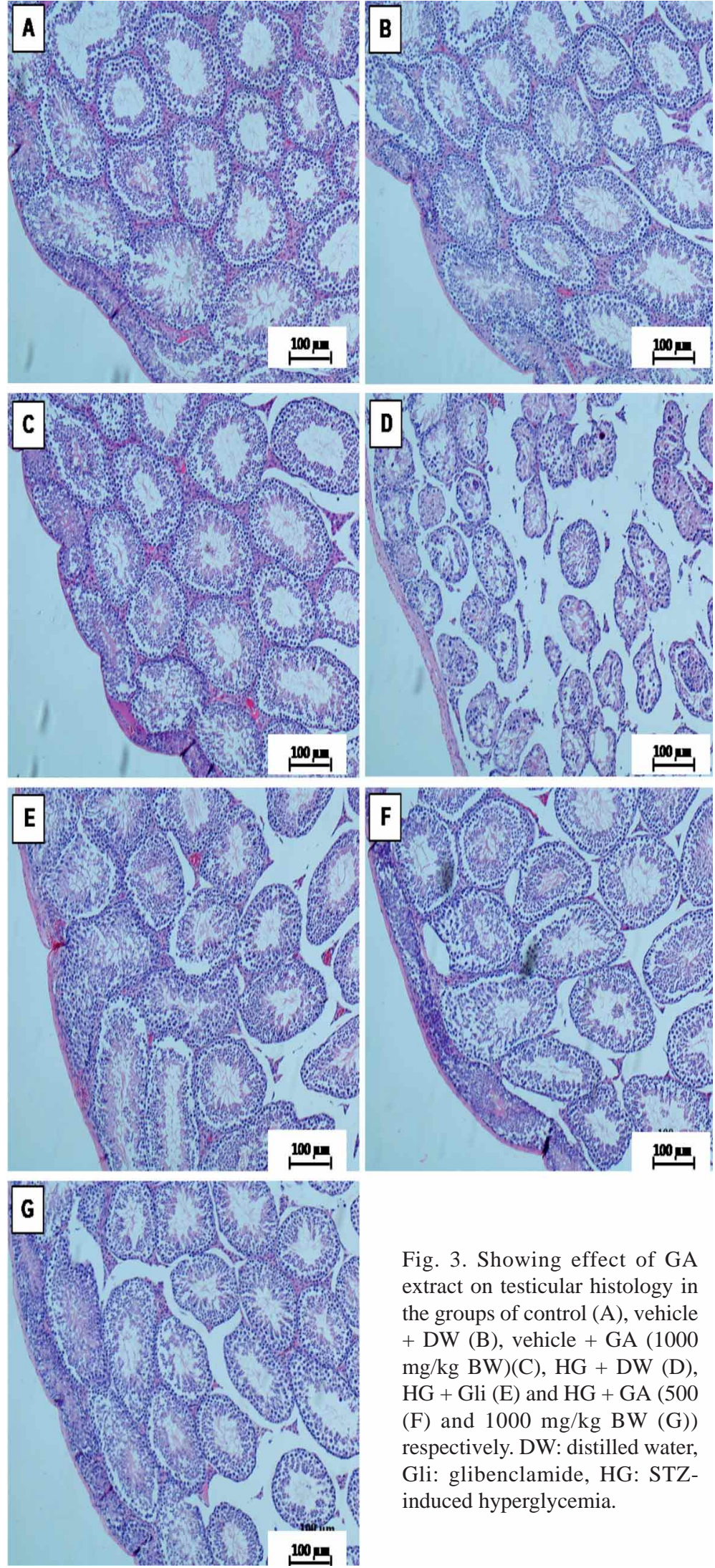

Fig. 3. Showing effect of GA extract on testicular histology in the groups of control (A), vehicle + DW $(\mathrm{B})$, vehicle + GA $(1000$ $\mathrm{mg} / \mathrm{kg} \mathrm{BW})(\mathrm{C}), \mathrm{HG}+\mathrm{DW}(\mathrm{D})$, $\mathrm{HG}+\mathrm{Gli}(\mathrm{E})$ and $\mathrm{HG}+\mathrm{GA}(500$ (F) and $1000 \mathrm{mg} / \mathrm{kg} \mathrm{BW}(\mathrm{G}))$ respectively. DW: distilled water, Gli: glibenclamide, HG: STZinduced hyperglycemia.

\section{RESULTS}

Total phenolic compound and antioxidant activity of GA extract.

Total phenolic compound: The absorbance of GA extract was represented by gallic acid standard linear equation $(y=0.0004 x+0.0748)$ (and calculated as compared with gallic acid concentration. The GA extract of $47.15 \pm 0.21$ $\mathrm{mg}$ possesses equivalence to $1.00 \mathrm{~g}$ of gallic acid (mg/g gallic acid equivalence, GAE).

Total flavonoid content: The absorbance of GA extract was represented by gallic acid standard linear equation $(y=0.0154 x+0.0484)$ and calculated as compared with quercetin concentration. The GA extract of $11.38 \pm 0.02$ $\mathrm{mg}$ possesses equivalence to $1.00 \mathrm{~g}$ of quercetin ( $\mathrm{mg} / \mathrm{g}$ quercetin equivalence, $\mathrm{QE}$ ).

DPPH free radical scavenging activity: The various concentration of GA extract scavenged the free radical in concentration-dependent DPPH free radical scavenging $(y=9.6929 x+$ 10.7938) with the IC50 of $40.44 \mu \mathrm{g} / \mathrm{ml}$ and maximum response of $67.29 \%$. Ascorbic acid showed eminent scavenging activity $(\mathrm{y}=$ $4.9724 \mathrm{x}+6.6005)$ with the IC50 of $8.07 \mu \mathrm{g} /$ $\mathrm{ml}$ and maximum response of $84.41 \%$.

Ferric reducing antioxidant power: The absorbance of GA extract was represented by gallic acid standard linear equation $(y=0.098 x$ +0.1333 ) and calculated as compared with ascorbic acid concentration. GA extract of $481.12 \pm 4.10 \mathrm{mg}$ possesses reducing equivalence to $1.00 \mathrm{~g}$ of ascorbic acid $\mathrm{mg} / \mathrm{g} \mathrm{GA}$ extract.

Effect of GA extract on morphology and weights of reproductive organs: Gli/GA 500 or 1000 could obviously improve testicular size as compared to HG group (Fig. 1). Contrasting, all HG groups had small size of reproductive organs as compared to those of control and vehicle (Fig. 2A).

In Figure 2A, the absolute and relative weight of testis tended to be improved after treatment with GA extract but they were not significantly different $(\mathrm{P}>0.05)$. However, all 


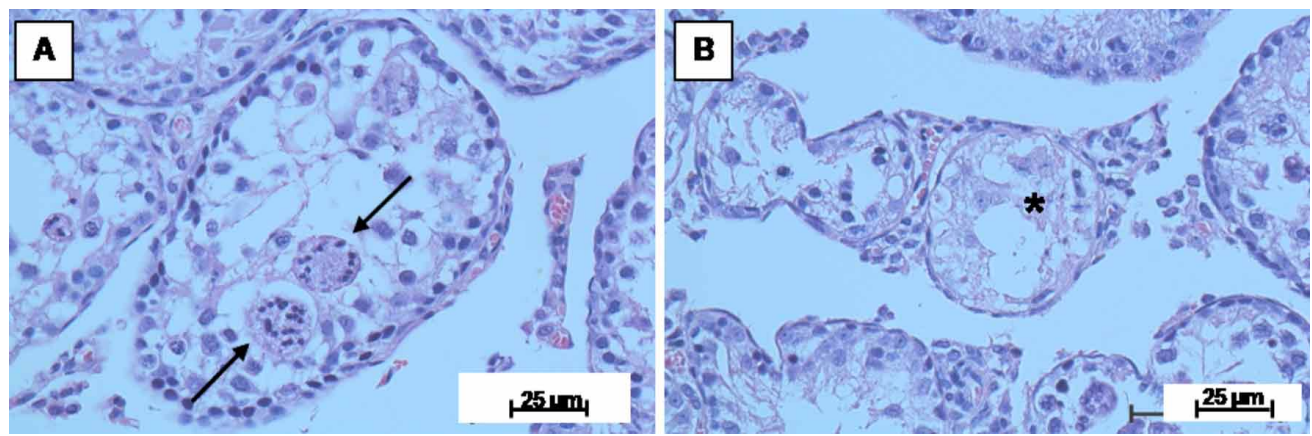

Fig. 4. Photographs showing the seminiferous histopathologies in HG-STZ mice. A) seminiferous atrophy with multinucleated giant cells (arrows) and B) atrophy with germ cells degeneration (asterisk).
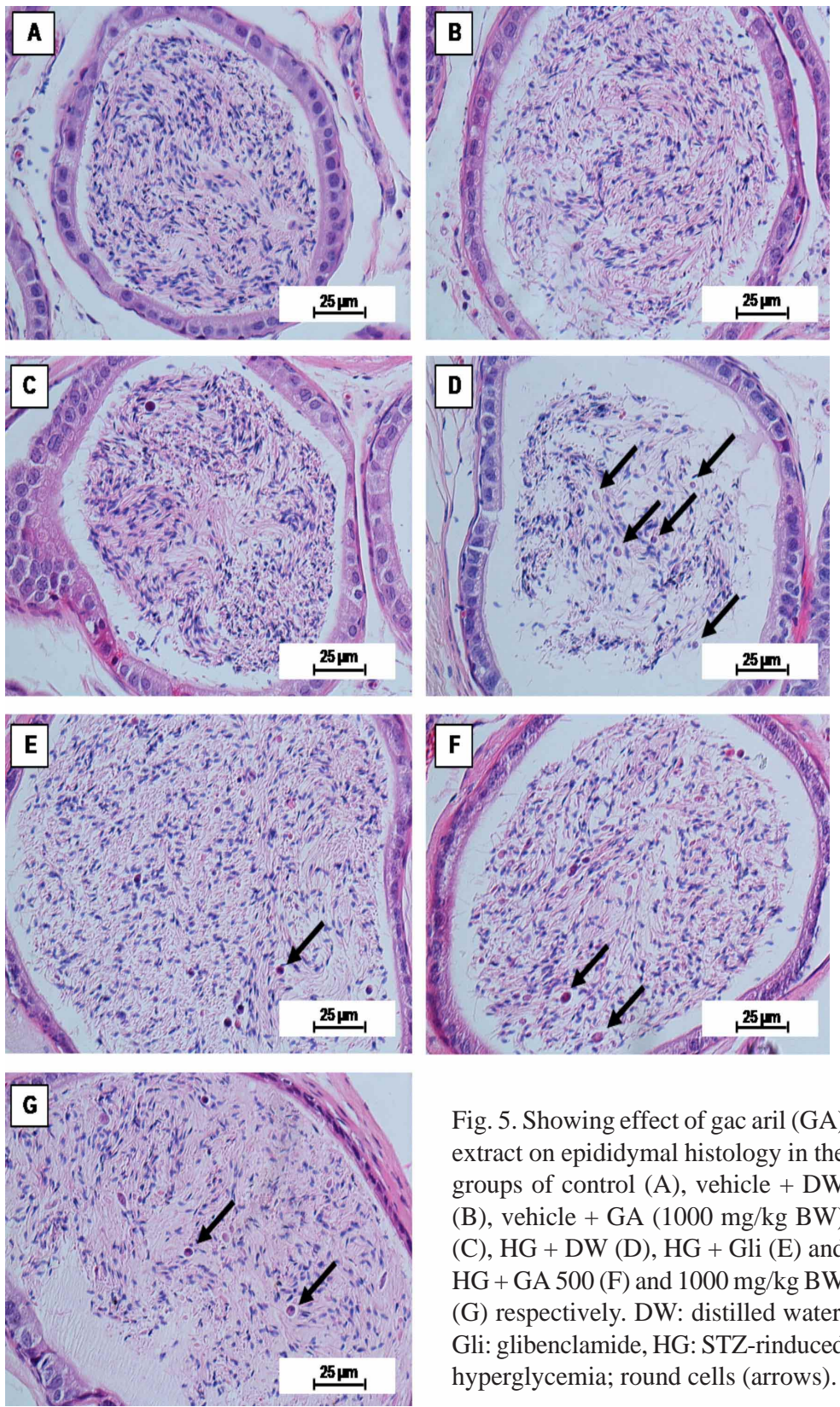

Fig. 5. Showing effect of gac aril (GA) extract on epididymal histology in the groups of control (A), vehicle + DW (B), vehicle + GA (1000 mg/kg BW) (C), HG + DW (D), HG + Gli (E) and $\mathrm{HG}+\mathrm{GA} 500$ (F) and $1000 \mathrm{mg} / \mathrm{kg} \mathrm{BW}$ (G) respectively. DW: distilled water, Gli: glibenclamide, HG: STZ-rinduced hyperglycemia; round cells (arrows).
HG groups had significantly decreased weight as compared to those of control and vehicle $(\mathrm{P}<0.05)$.

Effect of GA extracts on blood glucose levels STZ could induce mice to be actual HG condition with significantly elevated blood glucose levels (BGL) (average $388.21 \mathrm{mg} / \mathrm{dl}$ ) as compared to control (average $71.29 \mathrm{mg} / \mathrm{dl}$ ) $(\mathrm{P}<0.05)$ (Fig. 2B). After treatment, only GA extract 1000 and glibenclamide could significantly reduce $\mathrm{BGL}$ in $\mathrm{HG}$ mice as compared to HG-untreated group $(\mathrm{P}<0.05)$. In contrast, GA extract could not decrease BGL in GA-500 HG mice compared to HG-untreated group (Fig. 2B).

Effects of GA extract on sperm concentration and testosterone: In Figure 2C, Gli/GA 500 or 1000 can significantly improve sperm concentration compared to that of the HG group $(\mathrm{P}<0.05)$. However, sperm concentration in Gli-HG group was not different from GA treated groups (Fig. 2C). Interestingly, GA (1000 mg) tends to improve sperm concentration compared with HG-mice administered low dose of GA. It was noted that the sperm concentration of all $\mathrm{HG}$ groups were significantly reduced as compared to that of the non-HG groups (Fig. 2C).

The Gli/GA 500 or 1000 tends to slightly increase testosterone levels as compared to that of the HG group. However, the results showed that the testosterone levels were not significantly among treated groups (Fig. 2D).

Effect of GA extract on histology of testis and epididymis: The Gli/GA 500 or 1000 could improve testicular damages compared to that 
SAMPANNANG, A.; SUPATCHAREE A.; SUKHORUM, W.; BURAWAT, J.; NUALKAEW, S.; MANEENIN, C.; SRIPANIDKULCHAI, B. \& IAMSAARD, S. Antioxidant and hypoglycemic effects of Momordica cochinchinensis spreng (gac) aril extract on reproductive damages in streptozotocin (STZ)-induced hyperglycemia mice. Int. J. Morphol., 35(2):667-675, 2017.

of the untreated group (Fig. 3). In addition, GA 1000 alone did not affect testicular tissue. Indeed, STZ decreased spermatogenetic cells and increased atrophic tubule (Fig. 3D). Interestingly, GA extracts could improve testicular damage (Fig. 3F-G) similar to that of glibenclamide treatment (Fig. 3E).

The testicular histopathologies observed in $\mathrm{HG}$ mice were classified into two types (atrophy with multinucleated giant cells (Fig. 4A), and with germ cell degeneration (Fig. 4B).

The histologies of epididymis in control and experimental groups were shown in Figure 5. In general, the epithelial cells of all groups were not different. However, the density of sperm mass in GA 500/GA 1000-HG groups (Fig. 5E-F) was greater than that of HG group (Fig. 5D). Such density was similar to that of glibenclamide and control groups. The GA 1000 extract alone did not change the sperm mass (Fig. $5 \mathrm{C})$. In addition, STZ-induced groups were found to have various round cells within epididymal lumen (Fig. 5E).

Relative intensity of the testicular $70 \mathrm{kDa}$ phosphorylated proteins: The intensity of the $70 \mathrm{kDa}$ phosphorylated protein was divided by that of beta-actin (Fig. 6A). Its relative intensity in HG group was significantly increased compared with other groups $(\mathrm{P}<0.05)$ while that intensity of GA 1000 and control groups was not significantly different. It was found that relative intensity in GA/Gli-HG treated groups was significantly decreased as compared with the HG group $(\mathrm{P}<0.05)$ (Fig. 6B).

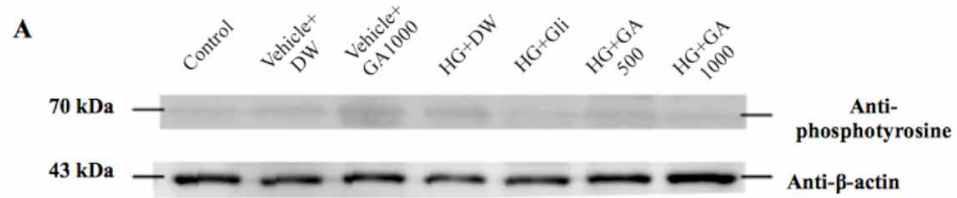

B

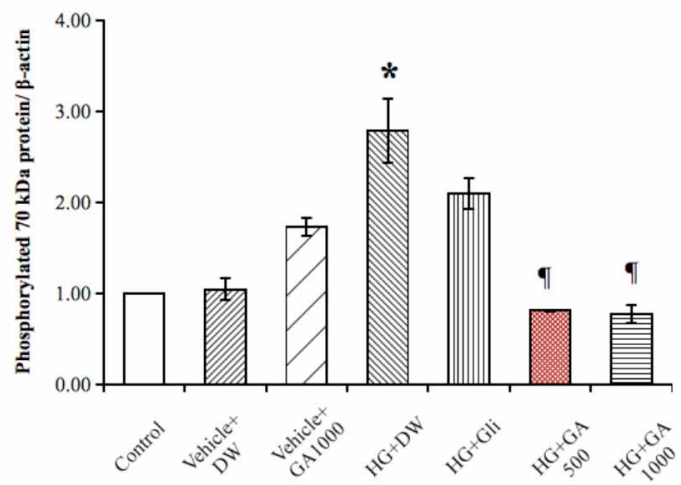

Fig. 5. Showing effect of gac aril (GA) extract on epididymal histology in the groups of control (A), vehicle + DW (B), vehicle + GA (1000 mg/kg BW) (C), $\mathrm{HG}+\mathrm{DW}(\mathrm{D}), \mathrm{HG}+\mathrm{Gli}(\mathrm{E})$ and HG + GA 500 (F) and $1000 \mathrm{mg} / \mathrm{kg} \mathrm{BW}(\mathrm{G})$ respectively. DW: distilled water, Gli: glibenclamide, HG: STZ-r induced hyperglycemia; round cells (arrows).

\section{DISCUSSION}

Kubola \& Siriamornpun reported that GA extracts were rich in total phenolic content. In comparisons, the antioxidant capacities determined in this study were closed to their results. A medicinal plant possessing antioxidants especially Momordica genus including GA can significantly reduce BGL in DM animals (Vajpeyi et al.). The treatments with GA extract in present study could also decrease BGL in HG mice. Although the doses of GA extracts treated in this study were higher than others, the LD50 of this extract documented in acute toxicity study was 2000 $\mathrm{mg} / \mathrm{kg} \mathrm{BW}$ (OECD, 2000). All experimental results indicated that $\mathrm{GA}$ extract has antioxidant capacity to reduce BGL in HG animals. In consistent with previous studies, the weights of male reproductive organs in DM animals were significantly decreased (Amaral et al., 2006; Scaranoet al., 2006). In this study, the reduction of epididymal weight was related to reduction of sperm concentration and epididymis histology. In contrast to other investigator (Ballester et al.), the serum testosterone in this study was not significantly decreased in HG mice compared to the control. A previous study described that treatment with plants possessing antioxidants improved glycemic imbalance (Amaral et al.). Similarly, GA extract could improve testicular weight and sperm concentration. In present study, GA extract improved testicular and epididymal damages compared to HG mice. It is possible that antioxidants in GA extract have protective capacity against free radical from STZ-HG induction. Interestingly, GA (1000 mg) was not toxic to male reproductive system.

It is known that phosphotyrosine proteins are important in the regulation cell proliferations, and differentiations in both normal and cancer cells (Ullrich \& Schlessinger, 1990). In post-translational modifications in male reproductive system, phosphotyrosine proteins are demonstrated to involve in sperm production, capacitation and acrosome reaction (Bailey, 2010; Iamsaardet al., 2014). Previously, Ballester et al. demonstrated that the presence of testicular 66 and $50 \mathrm{kDas}$ phosphorylated proteins were similar in the 
SAMPANNANG, A.; SUPATCHAREE A.; SUKHORUM, W.; BURAWAT, J.; NUALKAEW, S.; MANEENIN, C.; SRIPANIDKULCHAI, B. \& IAMSAARD, S. Antioxidant and hypoglycemic effects of Momordica cochinchinensis spreng (gac) aril extract on reproductive damages in streptozotocin (STZ)-induced hyperglycemia mice. Int. J. Morphol., 35(2):667-675, 2017.

healthy and DM rats with no different intensity. In the previous studies, plant extract processing antioxidant capacities could change the levels of testicular tyrosine protein phosphorylation in experimental animals (Iamsaard et al., 2013; 2014). In this study, only a $70 \mathrm{kDa}$ of testicular phosphorylated protein seemed to interrupt spermatogenesis increased in $\mathrm{HG}$ group and improved in GA groups. However, actual roles of the proteins need to be elucidated. In conclusion, GA could improve hyperglycemia and male reproductive damages in STZinduced hyperglycemia mice.

\section{ACKNOWLEDGMENTS}

We would like to gratefully thank the invitation research (No.IN58123), Faculty of Medicine, Khon Kaen University for financial support this project.

SAMPANNANG, A.; SUPATCHAREE A.; SUKHORUM, W.; BURAWAT, J.; NUALKAEW，S.; MANEENIN, C.; SRIPANIDKULCHAI, B. \& IAMSAARD, S. Efectos antioxidantes e hipoglucémicos del extracto de aril de Momordica cochinchinensis Spreng. (Gac) sobre los daños reproductivos en ratones con hiperglucemia inducida por streptozotocin (STZ). Int. J. Morphol., 35(2): 667675,2017

RESUMEN: El objetivo de este estudio fue investigar el efecto del extracto acuoso de Momordica cochinchinensis (Gag) aril (GA) en el sistema reproductor masculino de ratones hiperglucémicos inducidos por estreptozotocina (STZ). GA fue extraída con agua destilada (DW) y se analizaron las capacidades antioxidantes in vitro. Ratones ICR machos fueron divididos en 7 grupos: 1) control, 2) DW, 3) GA $1000 \mathrm{mg} / \mathrm{kg} \mathrm{PC}$, 4) HG, 5) HG + glibenclamida, 6 y 7) HG + GA 500 y 1000 mg / kg PC, respectivamente (7 ratones / grupo). En los grupos HG, los ratones fueron inducidos con STZ en dosis única (150 mg / kg BW). Fueron tratados durante 35 días consecutivos. En todos los grupos se compararon los niveles de glucosa en sangre, los pesos y las histopatologías de los órganos reproductores, la concentración de espermatozoides, incluídos los patrones testiculares de proteínas tirosina fosforilada por Inmuno-Western blot. Los resultados mostraron que GA procesaba actividades antioxidantes y podían disminuir significativamente los niveles de glucosa en sangre y aumentar la concentración de espermatozoides en ratones HG. Además, GA podría cambiar la densidad de una proteína testicular de 70 kDa en grupos HG-GA. En conclusión, el extracto de GA podría mejorar la hiperglucemia y los daños reproductivos masculinos inducidos por STZ en ratones HG.

PALABRAS CLAVES: Momordica cochinchinensis aril; Estreptozotocina; Daño testicular; Proteína fosforilada tirosina testicular; Hiperglucemia.

\section{REFERENCES}

Amaral, S.; Moreno, A. J.; Santos, M. S.; Seiça, R. \& Ramalho-Santos, J. Effects of hyperglycemia on sperm and testicular cells of GotoKakizaki and streptozotocin-treated rat models for diabetes. Theriogenology, 66(9):2056-67, 2006.

Baccetti, B.; La Marca, A.; Piomboni, P.; Capitani, S.; Bruni, E.; Petraglia, F. \& De Leo, V. Insulin-dependent diabetes in men is associated with hypothalamo-pituitary derangement and with impairment in semen quality. Hum. Reprod., 17(10):2673-7, 2002.

Bailey, J. L. Factors regulating sperm capacitation. Syst. Biol. Reprod. Med., 56(5):334-48, 2010.

Bakar, M. F. A.; Mohamed, M.; Rahmat, A. \& Fry, J. Phytochemicals and antioxidant activity of different parts of bambangan (Mangifera pajang) and tarap (Artocarpus odoratissimus). Food Chem., 113(2):479-83, 2009.

Ballester, J.; Muñoz, M. C.; Domínguez, J.; Rigau, T.; Guinovart, J. J. \& Rodríguez-Gil, J. E. Insulin-dependent diabetes affects testicular function by FSH- and LH-linked mechanisms. J. Androl., 25(5):70619, 2004.

Benzie, I. F. \& Strain, J. J. The ferric reducing ability of plasma (FRAP) as a measure of "antioxidant power": the FRAP assay. Anal. Biochem., 239(1):70-6, 1996.

Brand-Williams, W.; Cuvelier, M. E. \& Berset, C. Use of a free radical method to evaluate antioxidant activity. L.W. T. Food Sci. Technol., 28(1):25-30, 1995.

Chuethong, J.; Oda, K.; Sakurai, H.; Saiki, I. \& Leelamanit, W. Cochinin $\mathrm{B}$, a novel ribosome-inactivating protein from the seeds of Momordica cochinchinensis. Biol. Pharm. Bull., 30(3):428-32, 2007.

de Ferranti, S. D.; de Boer, I. H.; Fonseca, V.; Fox, C. S.; Golden, S. H.; Lavie, C. J.; Magge, S. N.; Marx, N.; McGuire, D. K.; Orchard, T. J.; Zinman, B. \& Eckel, R. H. Type 1 diabetes mellitus and cardiovascular disease: a scientific statement from the American Heart Association and American Diabetes Association. Circulation, 130(13):1110-30, 2014.

Iamsaard, S.; Burawat, J.; Kanla, P.; Arun, S.; Sukhorum, W.; Sripanidkulchai, B.; Uabundit, N.; Wattathorn, J.; Hipkaeo, W.; Fongmoon, D. \& Kondo, H. Antioxidant activity and protective effect of Clitoria ternatea flower extract on testicular damage induced by ketoconazole in rats. J. Zhejiang Univ. Sci. B, 15(6):548-55, 2014.

Iamsaard, S.; Prabsattroo, T.; Sukhorum, W.; Muchimapura, S.; Srisaard, P.; Uabundit, N.; Thukhammee, W. \& Wattanathorn, J. Anethum graveolens Linn. (dill) extract enhances the mounting frequency and level of testicular tyrosine protein phosphorylation in rats. J. Zhejiang Univ. Sci. B, 14(3):247-52, 2013.

Ishida, B. K.; Turner, C.; Chapman, M. H. \& McKeon, T. A. Fatty acid and carotenoid composition of gac (Momordica cochinchinensis Spreng) fruit. J. Agric. Food Chem., 52(2):274-9, 2004.

Jin, Y.; Shi, Y.; Zou, Y.; Miao, C.; Sun, B. \& Li, C. Fenugreek prevents the development of STZ-induced diabetic nephropathy in a rat model of diabetes. Evid. Based Complement. Alternat. Med., 2014:259368, 2014.

Kubola, J. \& Siriamornpun, S. Phytochemicals and antioxidant activity of different fruit fractions (peel, pulp, aril and seed) of Thai gac (Momordica cochinchinensis Spreng). Food Chem., 127(3):1138-45, 2011.

Organisation for Economic Cooperation and Development (OECD). Acute Oral Toxicity. Acute Oral Toxicity Class Method Guideline 423 Adopted 23-03-1996. In: Eleventh Addendum to the OECD guidelines for the Testing of Chemicals. Organisation for Economic Cooperation and Development. Paris, OECD, 2000.

Petchsak, P. \& Sripanidkulchai, B. Momordica cochinchinensis aril extract induced apoptosis in human MCF-7 breast cancer cells. Asian 
SAMPANNANG, A.; SUPATCHAREE A.; SUKHORUM, W.; BURAWAT, J.; NUALKAEW, S.; MANEENIN, C.; SRIPANIDKULCHAI, B. \& IAMSAARD, S. Antioxidant and hypoglycemic effects of Momordica cochinchinensis spreng (gac) aril extract on reproductive damages in streptozotocin (STZ)-induced hyperglycemia mice. Int. J. Morphol., 35(2):667-675, 2017.

Pac. J. Cancer Prev., 16(13):5507-13, 2015.

Scarano, W. R.; Messias, A. G.; Oliva, S. U.; Klinefelter, G. R. \& Kempinas, W. G. Sexual behaviour, sperm quantity and quality after short-term streptozotocin-induced hyperglycaemia in rats. Int. $J$. Androl., 29(4):482-8, 2006.

Singleton, V. L.; Orthofer, R. \& Lamuela-Raventos, R. M. Analysis of the Total Phenols and other Oxidation Substrates and Antioxidants by Means of Folin-Ciocateu Reagent. In: Packer, L. (Ed.). Methods in Enzymology. San Diego, Academic Press Inc., 1999. pp.152-78.

Tsoi, A. Y.; Ng, T. B. \& Fong, W. P. Immunomodulatory activity of a chymotrypsin inhibitor from Momordica cochinchinensis seeds. $J$. Pept. Sci., 12(9):605-11, 2006.

Ullrich, A. \& Schlessinger, J. Signal transduction by receptors with tyrosine kinase activity. Cell, 61(2):203-12, 1990.

Vajpeyi, A. P.; Sing, P. K.; Kumar, M.; Gupta, A. K. Sharma, M. K. \& Upadhyaya, S. R. Mode of action of Momordica cochinchinensis on serum glucose and insulin activity in streptozotocin induced diabetic rats. Asian J. Microbiol. Biotechnol. Environ. Sci., 9(4):779-82, 2007.

Wang, J.; Chen, H.; Zhang, H.; Yang, F.; Chen, R. P.; Li, Y. B.; Yang, C.; Lin, S. D.; Chen, L. S.; Liang, G. X. \& Cai, D. H. The performance of a diabetic retinopathy risk score for screening for diabetic retinopathy in Chinese overweight/obese patients with type 2 diabetes mellitus. Ann. Med., 4(6):417-23, 2014.

Zheng, Y.; Ren, C.; Lu, G.; Mu, Z.; Cui, W.; Gao, H. \& Wang, Y. Antidiabetic effect of mulberry leaf polysaccharide by inhibiting pancreatic islet cell apoptosis and ameliorating insulin secretory capacity in diabetic rats. Int. Immunopharmacol., 22(1):248-57, 2014.

\author{
Corresponding author: \\ Sitthichai lamsaard \\ Department of Anatomy \\ Faculty of Medicine \\ Khon Kaen University \\ 123 Mitraparp Road \\ Amphoe Muang, Khon Kaen 40002, \\ THAILAND
}

E-mail: sittia@kku.ac.th

Received: 07-10-2015

Accepted: 13-02-2017 